\title{
ANALISIS FINANSIAL DAN KOMPOSISI TANAMAN DALAM RANGKA PERSIAPAN PENGAJUAN IZIN HKm (STUDI KASUS DESA MARGOSARI KECAMATAN PAGELARAN UTARA KABUPATEN PRINGSEWU)
}

\section{(FINANCIAL ANALYSIS AND COMPOSITION OF PLANTS IN PREPARATION FOR HKm FILING PERMITS (A CASE STUDY OF MARGOSARI VILLAGE OF PAGELARAN UTARA SUBDISTRICT OF PRINGSEWU DISTRICT))}

\author{
Helen Yuseva Ayu, Rommy Qurniati, dan Rudi Hilmanto \\ Jurusan Kehutanan, Fakultas Pertanian Universitas Lampung \\ J1. Soemantri Brojonegoro No. 1 Telephone 704946 Bandar lampung 35145 \\ e-mail: me_helenyuseva@yahoo.com
}

\begin{abstract}
ABSTRAK
Hutan kemasyarakatan $(\mathrm{HKm})$ adalah hutan negara yang pemanfaatan utamanya ditujukan untuk memberdayakan masyarakat setempat dengan tujuan agar hutan lestari, masyarakat sejahtera. Desa Margosari saat ini dalam tahap penyusunan proposal izin penetapan areal kerja HKm ke Menteri Kehutanan Republik Indonesia. Salah satu syarat pengajuan izin HKm adalah komposisi tanaman terdiri atas jenis tanaman kehutanan, pertanian, dan perkebunan. Untuk mendukung program HKm perlu dikaji komposisi tanaman di lahan calon HKm Desa Margosari dan apakah hasil tanaman berdasarkan komposisi tersebut layak secara finansial dan mampu mensejahterakan petani Desa Margosari. Penelitian dilaksanakan di Desa Margosari Kecamatan Pagelaran Utara Kabupaten Pringsewu pada bulan Agustus 2013. Pengambilan sampel dilakukan menggunakan simple random sampling. Analisis data menggunakan metode analisis deskriptif kuantitatif. Hasil penelitian menunjukkan bahwa komposisi tanaman telah memenuhi kriteria HKm yaitu jumlah tanaman kayu lebih dari 200 batang/ha (400 batang/ha) dengan jenis tanaman kehutanan sebesar 28,88\%, tanaman pertanian sebesar 14,63\%, dan tanaman perkebunan sebesar 56,49\%. Hasil agroforestri HKm berdasarkan analisis layak secara finansial dengan Net Present Value (NPV) sebesar Rp 69.088.522,37/Ha, Benefit Cost Ratio (BCR) sebesar 1,96 dan Internal Rate of Return (IRR) sebesar 29\%. Namun, berdasarkan tingkat kesejahteraan dengan kriteria Sajogyo (1997) pendapatan dari agroforestri HKm belum dapat mensejahterakan petani, karena masih terdapat penduduk dengan kategori nyaris miskin sebesar 51,52\%.
\end{abstract}

Kata kunci : Hutan kemasyarakatan, komposisi tanaman, analisis finansial, kesejahteraan

\section{ABSTRACT}

Social forestry $(\mathrm{HKm})$ is a state forest utilization primarily intended to empower local communities with a purpose sustainable forest and prosperous society. Margosari village currently proposing for HKm the work area permits the Minister of Forestry Republic of Indonesia. One of the requirements to HKm is composition of plants consists of the kind of forest plant, agricultural crops, and crops plantation. To supporting the HKm programs, it is necessary to assess the composition of the plants with in the candidate HKm area of Margosari Village and whether the results from the plant composition is financially suitable and capable of providing prosperity to the farmers of Margosari village. The research was conducted in the Margosari Village of Pagelaran Utara District, Pringsewu Regency in August 2013. Sampling was done using simple random sampling method. Data analysis was conducted using quantitative descriptive analysis method. The results of the showed that the 
plant composition already fill the HKm criteria is wooden plant more than 200/ha (400/ha) with forest plant species of $28.88 \%$, agricultural crops of $14.63 \%$ of agricultural crops and crops plantation of 56.49\%. The result from agroforestry $\mathrm{HKm}$ based on analysis in a financially Net Present Value (NPV) of Rp 69.088.522.37/ha, Benefit Cost Ratio (BCR) of 1.96 and Internal Rate of Return (IRR) of 29\%. However the level of Sajogyo (1997), income from agroforestry $\mathrm{HKm}$ don't providing prosperity to the farmers, because can still population with a category near poor of $51.52 \%$.

Keywords: social forest, composition of plants, financial analysis, welfare

\section{PENDAHULUAN}

Berdasarkan Peraturan Menteri No. 37/Menhut-II/2007, hutan kemasyarakatan (HKm) adalah hutan negara yang pemanfaatan utamanya ditujukan untuk memberdayakan masyarakat setempat. Kegiatan Hkm hanya diberlakukan di kawasan hutan lindung dan hutan produksi. Komoditi tanaman yang digunakan dalam hutan kemasyarakatan harus dipilih sesuai dengan karakteristik daerah dan lahan yang akan ditanami. Secara teknis pemilihan jenis komoditi mempertimbangkan faktor fisik/ekologi, faktor sosial ekonomi dan sosial budaya (Wardoyo, 1997).

Kegiatan HKm ditujukan bagi masyarakat petani di sekitar kawasan hutan, yang memiliki ketergantungan pada kawasan hutan tersebut dengan sistem pendekatan areal kelola atau hamparan kelola. Kelompok tani HKm dianjurkan menanam tanaman dengan jenis MPTS (Multi Purpose Trees Species). Manfaat penerapan sistem tanam yang multi-guna seperti ini diharapkan dapat dinikmati oleh masyarakat sehingga meningkatkan kesejahteraan hidup masyarakat melalui keanekaragaman hasil tanaman di lahan HKm.

Desa Margosari memiliki lahan garapan dalam kawasan hutan saat ini sudah membentuk kelompok yang tergabung dalam gabungan kelompok tani (Gapoktan) dan sekaramg pada tahap penyusunan proposal dalam rangka mengajukan penetapan areal kerja HKm kepada Menteri Kehutanan Republik Indonesia (RI) (Dinas Kehutanan Provinsi Lampung, 2011). Petani Desa Margosari menerapkan sistem agroforestri dalam mengelola lahannya. Penerapan sistem agroforestri dapat mengurangi tingkat ketergantungan pengumpulan hasil hutan berupa kayu. Oleh karena itu perlu dilakukan penelitian yang bertujuan untuk mengetahui komposisi tanaman di lahan $\mathrm{HKm}$ Desa Margosari dan mengetahui apakah hasil tanaman berdasarkan komposisi tanaman tersebut layak secara finansial dan mampu mensejahterakan petani Desa Margosari.

\section{METODE PENELITIAN}

Penelitian dilaksanakan di Desa Margosari, Kecamatan Pagelaran Utara, Kabupaten Pringsewu pada bulan Agustus 2013. Alat yang digunakan dalam penelitian ini adalah alat tulis, kamera, kuesioner, kalkulator, dan komputer. Objek penelitian adalah petani yang mengusulkan izin HKm di Desa Margosari Kecamatan Pagelaran Utara Kabupaten Pringsewu. Data yang diambil penelitian ini adalah data primer meliputi identitas responden, komposisi tanaman, pendapatan mengelola lahannya meliputi jenis tanaman, dan biaya produksi. Data sukunder meliputi keadaan umum lokasi penelitian, sosial ekonomi masyarakat, dan referensi penunjang lainnya. Data primer diperoleh dengan pengamatan langsung di lapangan dan wawancara dengan responden, data sekunder diperoleh dengan studi pustaka. 
Populasi dalam penelitian ini diambil secara purposive sampling. Tujuan pemilihan populasi dengan purposive sampling untuk memenuhi kriteria yang diperlukan dalam penelitian yaitu petani yang mengajukan izin HKm. Jumlah petani yang mengajukan izin HKm sebanyak 190. Berdasarkan rumus Rakhmat (2001) dengan presisi 15\% diperoleh jumlah responden 33 orang. Sampel dalam penelitian ini dipilih dengan metode simple random sampling.

Metode pengolahan dan analisis data:

\section{Komposisi tanaman}

Komposisi tanaman terdiri atas tanaman kehutanan, tanaman pertanian, dan tanaman perkebunan. Defisini operasional ketiga jenis tanaman tersebut adalah sebagai berikut:

a. Tanaman kehutanan: jenis tanaman keras yang dibudidayakan pada kawasan kehutanan seperti jati, pinus, rasamala, puspa,kamper dan sejenisnya (Perda Nomor 8 Tahun 2004).

b. Tanaman pertanian: segala tanaman yang digunakan oleh manusia untuk tujuan apapun yang berguna secara ekonomi maupun kehidupan manusia (Setyati,1982)

c. Tanaman perkebunan: tanaman yang dikelompokkan menjadi 2 yaitu:

1. Tanaman tahunan: tanaman perkebunan yang umumnya berumur lebih dari satu tahun dan pemungutan hasilnya dilakukan lebih dari satu kali masa panen untuk satu kali pertanaman.

2. Tanaman semusim: tanaman perkebunan yang pada umumnya berumur pendek dan panennya dilakukan satu atau beberapa kali masa panen (keprasan) untuk satu kali penanaman (UU No 18 Tahun 2004).

Komposisi tanaman diolah dalam bentuk tabulasi dan dianalisis secara deskriptif kualitatif untuk penjelasan dari tabulasi.

\section{Analisis finansial}

Analisis finansial dilakukan dengan menghitung Net Present Value (NPV), Benefit Cost Ratio (BCR), Internal Rate of Return (IRR). Rumus yang digunakan adalah sebagai berikut (Suharjito, dkk, 2003):

a. Net Present Value (NPV)

Net Present Value merupakan selisih antara penerimaan dengan biaya. Penerapan pola tanam menguntungkan apabila NPV $>0$, sebaliknya jika NPV $<0$ berarti tidak menguntungkan.

NPV = PVpenerimaan - PVpengeluaran
$=\quad{ }_{t=1}^{\text {PV }} \frac{\mathrm{Bt}}{(1+\mathrm{i})^{-}} \quad{ }_{t=1}^{t} \frac{\mathrm{Ct}}{(1+\mathrm{i})^{\mathrm{t}}}={ }_{t=1}^{\frac{\mathrm{Bt}-\mathrm{Ct}}{(1+\mathrm{i})^{\mathrm{t}}}}$

Keterangan:

$\mathrm{NPV}=$ nilai bersih sekarang $(\mathrm{Rp})$

$\mathrm{PV}=$ nilai sekarang $(\mathrm{Rp})$

$\mathrm{Bt}=$ manfaat yang diperoleh setiap tahun (Rp)

$\mathrm{Ct} \quad=$ biaya yang dikeluarkan setiap tahun $(\mathrm{Rp})$

$\mathrm{i} \quad=$ suku bunga $(12 \%)$

$\mathrm{t} \quad=$ periode waktu (20 tahun)

b. Benefit Cost Ratio (BCR)

Penerapan pola tanam agroforestri dapat dikatakan menguntungkan apabila nilai Net $\mathrm{B} / \mathrm{C}>1$ dan sebaliknya apabila $\mathrm{B} / \mathrm{C}<1$ berarti pola tanam tidak menguntungkan. 


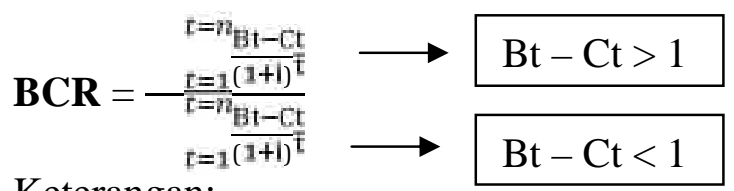

Keterangan:

$\mathrm{BCR}=$ perbandingan antara pendapatan dan pengeluaran.

c. Internal Rate of Return (IRR)

Penerapan pola tanam agroforestri dikatakan menguntungkan apabila IRR $>i$.

Keterangan:

$$
\text { IRR }=i_{1}+\frac{N P V_{1}}{N P V_{2}-N P V_{1}} \times i_{2}-i_{1}
$$

IRR = suku bunga maksimum yang dapat dibayar oleh suatu proyek $(\%)$

$\mathrm{NPV}_{1}=$ nilai NPV yang positif pada tingkat suku bunga tertentu (Rp)

$\mathrm{NPV}_{2}=$ nilai NPV yang negatif pada tingkat suku bunga tertentu (Rp)

$\mathrm{i}_{1}=$ tingkat bunga pertama dimana diperoleh NPV Positif (\%)

$\mathrm{i}_{2}=$ tingkat bunga kedua dimana diperoleh NPV Negatif $(\%)$.

\section{Tingkat kesejahteraan rumah tangga petani}

Tingkat kesejaheraan rumah tangga petani didasarkan pada pendapatan dari agroforestri yang dikonversikan menjadi besarnya pengeluaran per kapita per tahun yang diukur dengan harga atau nilai beras setempat menurut Sajogyo (1997) yang dimodifikasi sesuai kebutuhan penelitian.

Pendapatan/Kapita Keluarga/ = Pendapatan Agroforestri/tahun $(\mathrm{Rp})$

Tahun (Rp) Jumlah tanggungan keluarga

Pengeluaran $/$ Kapita Keluarga/ = Pendapatan $/$ kapita RT/tahun $(\mathrm{Rp})$

Setara beras $(\mathrm{Kg}) \quad$ Harga beras $(\mathrm{Rp} / \mathrm{Kg})$

Keterangan:

Pengeluaran $=$ Jumlah biaya yang dikeluarkan dalam kapita RT tahun $(\mathrm{Rp})$

Pendapatan = Jumlah yang diterima dalam kapita RT/tahun (Rp)

Harga beras $=$ Harga atau nilai beras setempat $(\mathrm{Rp} / \mathrm{kg})$

Jumlah tanggungan keluarga = Jumlah tanggungan keluarga dalam kapita keluarga.

Sajogyo (1997), petani miskin dikelompokan kedalam enam golongan yaitu:
(1) Paling miskin
: pendapatan per kapita keluarga, $180 \mathrm{~kg}$ setara beras/tahun
(2) Miskin sekali
: 181--240 kg setara beras/tahun
(3) Miskin
: 241--320 kg setara beras/tahun
(4) Nyaris miskin
: 321--480 kg setara beras/tahun
(5) Cukup
: 481--960 kg setara beras/tahun
(6) Hidup layak
: >960 kg setara beras/tahun.

\section{HASIL DAN PEMBAHASAN}

\section{A. Komposisi Tanaman}

Petani Desa Margosari dalam pengelolaan lahan garapannya menerapkan sistem agroforestri dengan mengkombinasikan tanaman kehutanan dengan tanaman pertanian dan perkebunan. Ketiga jenis tanaman tersebut membentuk suatu komposisi tanaman yang dapat dilihat pada Tabel 1.

Tabel 1. Komposisi Tanaman di Desa Margosari 


\begin{tabular}{|c|c|c|c|c|c|}
\hline No & $\begin{array}{c}\text { Klasifikasi } \\
\text { Jenis Tanaman }\end{array}$ & $\begin{array}{c}\text { Jenis } \\
\text { Tanaman }\end{array}$ & Nama Latin & $\begin{array}{c}\text { Jumlah Tanaman } \\
\text { (batang) }\end{array}$ & $\begin{array}{c}\text { Persentase } \\
(\%)\end{array}$ \\
\hline \multirow[t]{8}{*}{$\mathbf{A}$} & $\begin{array}{l}\text { Tanaman } \\
\text { Kehutanan }\end{array}$ & Bayur & $\begin{array}{l}\text { Pterospermum } \\
\text { javanicum }\end{array}$ & 284 & 0,59 \\
\hline & & Jati & Tectona grandis & 455 & 0,94 \\
\hline & & Johar & Cassia siamea & 235 & 0,49 \\
\hline & & Karet & Hevea brasiliensis & 11.680 & 24,24 \\
\hline & & Mahoni & Swietenia Mahagoni & 523 & 1,09 \\
\hline & & Pulai & Alstonia scholaris & 215 & 0,45 \\
\hline & & Sengon & $\begin{array}{l}\text { Paraserianthes } \\
\text { falcataria }\end{array}$ & 346 & 0,72 \\
\hline & & Winong & Tetrameles nudiflora & 177 & 0,37 \\
\hline \multicolumn{2}{|c|}{ Jumlah } & & & 13.915 & 28,88 \\
\hline B & $\begin{array}{l}\text { Tanaman } \\
\text { Pertanian }\end{array}$ & Pisang & Musa sp & 7.050 & 14,63 \\
\hline \multicolumn{2}{|c|}{ Jumlah } & & & 7.050 & 14,63 \\
\hline \multirow[t]{12}{*}{$\mathbf{C}$} & $\begin{array}{l}\text { Tanaman } \\
\text { Kehutanan }\end{array}$ & Alpukat & Persea gratissima & 250 & 0,52 \\
\hline & & Cengkeh & Eugenia aromatic & 532 & 1,10 \\
\hline & & Duku & Lansium domesticum & 67 & 0,14 \\
\hline & & Durian & Durio zibethinus & 995 & 2,07 \\
\hline & & Jengkol & $\begin{array}{l}\text { Pithecollobium } \\
\text { jiringa }\end{array}$ & 568 & 1,18 \\
\hline & & Kakao & Theobroma cacao & 14.050 & 29,16 \\
\hline & & Kelapa & Cocos nucifera & 605 & 1,26 \\
\hline & & Kopi & Coffea robusta & 8.700 & 18,06 \\
\hline & & Lada & Piper nigrum & 415 & 0,86 \\
\hline & & Nangka & Artocarpus integra & 236 & 0,49 \\
\hline & & Pala & Myristica fragrans & 50 & 0,10 \\
\hline & & Petai & Parkia speciosa & 751 & 1,56 \\
\hline \multicolumn{2}{|c|}{ Jumlah } & & & 27.219 & 56,49 \\
\hline \multicolumn{2}{|c|}{ Total } & & & 48.184 & 100,00 \\
\hline
\end{tabular}

Sumber: Data Primer diolah (2013)

Tabel 1 menunjukkan bahwa komposisi tanaman didominasi oleh tanaman perkebunan dengan jumlah persentase $56,49 \%$. Jenis tanaman perkebunan didominasi oleh tanaman kakao (Theobroma cacao) sebesar 29,16\%. Kakao merupakan salah satu komoditi perkebunan yang berperan penting dalam perekonomian Indonesia. Petani Desa Margosari menanam tanaman kakao dengan pola tanam agroforestri. Agroforestri salah satu cara meningkatkan produktivitas dilahan kering. Petani kakao menggunakan jarak tanam 3 x $3 \mathrm{~m}$ dan ada juga menggunakan jarak $3 \times 4 \mathrm{~m}$. kakao sangatlah menguntungkan bagi petani karena proses pemanennya dilakukan 2 minggu sekali atau satu bulan sekali dan mulai berproduksi pada umur 4 tahun. Panen raya dilakukan dua periode dalam setahun. Periode pertama, berlangsung pada bulan April--Juni dengan puncak periode Bulan Mei dan periode kedua berlangsung pada bulan September-Nopember dengan puncak periode Bulan Oktober. Pemeliharaan kakao dilakukan petani desa Margosari dengan pemupukan dan pemangkasan. Pemupukan dilakukan untuk merangsang pertumbuhan dan peningkatan produksi sedangkan pemangkasan dilakukan untuk mencegah terserang hama, selain itu bentuk pengendalian hama dengan menggunakan pestisida. Salah satu cara pengendalian yang relatif murah dan mudah serta aman terhadap lingkungan adalah pengendalian dengan menggunakan pestisida nabati dan agensia hayati (Siswanto dan Karmawati, 2012). Namun, petani Desa Margosari belum menerapkan cara pengendalian hama dengan menggunakan pestisida nabati dan agensia hayati. 
Komposisi tanaman untuk jenis tanaman pertanian didominasi oleh tanaman pisang (Musa spp) dengan persentase sebesar 14,63\%. Jenis-jenis pisang ditanam petani seperti kepok dan jantan. Desa Margosari merupakan salah satu menghasilkan pisang yang cukup besar di Kabupaten Pringsewu. Penjualan pisang telah dikirim ke kota-kota seperti Jakarta. Frekuensi panen per satuan waktu pisang satu bulan sekali atau 20 hari sekali. Satu kali panen jumlah produksi sebanyak 200--400 per kilogram, satu kilogram dihargai Rp 1.000,00. Hasil panenan dijual ke pengumpul dan pengumpul menjualnya ke pasar setempat atau langsung dijual ke luar kota. Sebagian besar petani berusaha tani dengan menanam tanaman pisang karena keuntungan yang dihasilkan cukup besar dan dapat memenuhi kebutuhan hidup sehari-hari.

Tanaman kehutanan didominasi oleh tanaman karet (Havea brasiliensis) dengan persentase sebesar 24,24\%. Karet merupakan tanaman kehutanan yang dapat dimanfaatkan hasil hutan bukan kayu berupa getah. Tanaman karet mulai dapat disadap pada umur 8 tahun. Penyadapan getah karet dilakukan petani setiap hari mulai pagi sampai menjelang sore. Waktu penyadapan yang baik dilakukan dari pukul 05.00 pagi sampai pukul 10.00 pagi agar menghasilkan getah lateks yang baik (Sannia, 2013). Getah karet yang sudah disadap dikumpulkan sampai banyak kemudian dijual dengan harga Rp $10.000,00 / \mathrm{kg}$. Petani Desa Margosari mulai banyak yang menanam tanaman karet selain menghasilkan keuntungan yang besar yaitu dapat mengurangi ketergantungan pengumpulan hasil hutan berupa kayu. Berdasarkan Peraturan Menteri No. P.14/Menhut-II/2012 tentang Pedoman Penyelenggaraan Rehabilitasi Hutan dan Lahan Tahun 2012, kegiatan rehabilitasi kawasan hutan konservasi/lindung dilakukan dengan pengayaan tanaman kayu minimum 200 batang/ha. Jumlah tanaman kayu yang ada di lahan areal HKm Desa Margosari rata-rata berjumlah 400 batang/ha, berarti petani telah menerapkan komposisi tanaman yang dapat mengoptimalkan suatu bentuk penggunaan lahan secara berkelanjutan sehingga kawasan pengelolaan HKm sesuai fungsi pokok dan peruntukannya.

\section{B. Analisis Finansial}

a. Pendapatan petani Desa Margosari

Pendapatan Petani Desa Margosari diperoleh dari penerimaan hasil pengusahaan agroforestri dan non agroforestri. Hasil penerimaan agroforestri diperoleh dari jenis tanaman yaitu karet (Havea brasiliensis), kelapa (Cocos nucifera), durian (Durio zibethinus), lada (Piper ningrum), nangka (Artocarpus heterophyllus), jengkol (Pithecollobium jiringa), cengkeh (Eugenia aromatica), dan petai (Parkia speciosa), pisang (Musa sp), kakao (Theobroma cacao) dan kopi (Coffea robusta). Sedangkan hasil penerimaan non agroforestri diperoleh dari berdagang, buruh bangunan, buruh tani, pedagang ikan, peternak dan pensiunan.

Penerimaan yang didominasi dari petani dalam mengelola lahannya yaitu pada tanaman kakao. Penerimaan total tanaman kakao selama 20 tahun yaitu sebesar Rp 153.763.333,33 ha/th dan total penerimaan tanaman kopi yaitu sebesar Rp 50.650.000,00 ha/th. Penerimaan total tanaman pisang diperoleh sebesar Rp 71.856.000,34 ha/th. Sedangkan total penerimaan tanaman jengkol selama 20 tahun sebesar Rp 9.608.333,34 ha/th, petai sebesar Rp 9.483.333,33 ha/th, durian sebesar Rp 45.911.6666,67 ha/th, kelapa sebesar Rp 5.696.666,67 ha/th, lada sebesar Rp 68.276.333,33 ha/th, nangka sebesar Rp 3.058.333,34 ha/th, cengkeh sebesar Rp 44.400.000,00 ha/th, dan karet sebesar Rp 68.535.000,00 ha/th. Dari hasil penelitian 
total penerimaan yang diperoleh petani Desa Margosari selama 20 tahun yaitu sebesar Rp 531.239.000,01 ha/th.

Rata-rata penerimaan dari hasil non agroforestri yaitu sebesar Rp 75.223.984,58/th. Rata-rata penerimaan berdagang diperoleh sebesar Rp 7.375.000,00/th. Rata-rata penerimaan buruh bangunan diperoleh sebesar Rp $8,400,000,00 /$ th. Rata-rata penerimaan buruh tani diperoleh sebesar Rp 4.126.386,42/th. Rata-rata penerimaan pedagang ikan diperoleh sebesar Rp 9.000.000,00/th. Rata-rata penerimaan peternak diperoleh sebesar Rp 7.600.000,00/th dan rata-rata penerimaan pesiun diperoleh sebesar $\mathrm{Rp} 25.602 .000,00 /$ th.

Pengusahaan lahan agroforestri dalam penelitian ini diasumsikan selama 20 tahun disesuaikan dengan umur ekonomis kakao sebagai tanaman utama yang paling dominan (Siregar dkk, 2007). Penerimaan yang diperoleh dari petani Desa Margosari membutuhkan biaya-biaya yang harus dikeluarkan, biaya tersebut dikeluarkan selama waktu pengelolaan. Komponen biaya yang dikeluarkan antara lain bibit, pupuk, pestisida, tenaga kerja, dan peralatan. Penggunaan masing-masing komponen biaya tersebut mempengaruhi manfaat ekonomis yang diperoleh petani, tergantung dari besar kecilnya komponen biaya yang digunakan. Besar pengeluaran komponen biaya antara lain bibit sebesar Rp 5.933.333,34 ha/th, pupuk sebesar Rp 19.713.749,66 ha/th, pestisida sebesar Rp 5.169.333,34 ha/th, peralatan sebesar Rp 6.996.166,68 ha/th, dan tenaga kerja sebesar Rp 127.918.333,33 ha/th. Besarnya total komponen biaya pengeluaran sebesar Rp 165.730.916,35 ha/th.

\section{b. Kelayakan Usaha}

Berdasarkan hasil perhitungan diperoleh nilai Net Present Value (NPV) sebesar Rp 69.088.522,37/Ha. Nilai NPV tersebut menunjukkan manfaat secara ekonomis yang diterima pada pengusahaan komposisi tanaman. Nilai Benefit Cost Ratio (BCR) sebesar 1,96 yang berarti dari setiap rupiah biaya yang dikeluarkan menghasilkan keuntungan Rp 1,96-. Nilai Internal Rate of Return (IRR) pada suku bunga 12\% diperoleh sebesar $29 \%$ yang berarti dari setiap rupiah yang diinvestasikan selama umur pengusahaan akan memberikan pengembalian modal $29 \%$ maka secara finansial komposisi tanaman menguntungkan/layak untuk diusahakan oleh petani. Hasil ini sejalan dengan penelitian yang dilakukan oleh Syahrani dan Husainie (2003) tentang analisis kelayakan finansial pengusahaan kebun hutan dengan tanaman buah durian di Kabupaten Kutai Kertanegara Propinsi Kalimantan Timur diperoleh Net Present Value (NPV) sebesar Rp. 7.982.175 dan Net B/C Ratio sebesar 2,12 dinilai pada tingkat bunga 15\%, sedangkan Internal Rate of Return (IRR), diperoleh sebesar 20,95\% dan penelitian Bambang, dkk (2004) tentang analisis kelayakan finansial usahatani lada (Piper ningrum, L) di Desa Kunduran Kecamatan Ulu Musi Kabupaten Lahat Sumatera Selatan diperoleh Net Present Value (NPV) sebesar Rp. 46.311.720,00 dan Net B/C Ratio sebesar 1,5 dinilai pada tingkat bunga 15\%, sedangkan Internal Rate of Return (IRR), diperoleh sebesar 37,50\%. Dengan demikian dapat dikatakan bahwa secara finansial hasil tanaman dengan pola agroforestri menguntungkan, namun tingkat keuntungannya tidak terlalu tinggi.

\section{Kesejahteraan Petani Desa Margosari}

Kebutuhan rumah tangga petani berdasarkan pengeluaran pangan dan pengeluaran non pangan. Rata-rata pengeluaran rumah tangga petani Desa Margosari tahun 2013 disajikan pada Tabel 2. Petani di Desa akan lebih mengutamakan pemenuhan kebutuhan pangan daripada kebutuhan non pangan. Petani akan memenuhi kebutuhan primernya 
terlebih dahulu dan seiring berjalannya waktu kebutuhan sekunder dan tersier pun akan terpenuhi secara perlahan-lahan.

Tabel 2. Rata-rata pengeluaran rumah tangga petani Desa Margosari tahun 2013.

\begin{tabular}{clcc}
\hline No. Jenis Pengeluaran & Rata-rata & Pengeluaran $(\mathbf{R p / t h})$ & Persentase $\mathbf{( \% )}$ \\
\hline $1 \quad$ Pangan/bln & & \\
& Padi, tepung, dan mie instans & $3.024 .500,00$ & 13,74 \\
Minyak dan lemak & $258.181,82$ & 1,17 \\
Sumber protein hewani & $1.554 .000,00$ & 7,06 \\
Sumber protein nabati & $268.363,64$ & 1,22 \\
Gula & $299.636,36$ & 1,36 \\
Sayuran & $896.181,82$ & 4,07 \\
Buahan & $104.363,64$ & 0,47 \\
Bumbu & $938.727,27$ & 4,27 \\
Minuman (teh, kopi, susu) & $312.181,82$ & 1,42 \\
Pengeluaran pangan tahunan & $303.030,30$ & 1,38 \\
\hline Total Pengeluaran/tahun & $7.959 .167,00$ & 36,17 \\
Non Pangan & & \\
Kesehatan & $534.545,45$ & 2,43 \\
Pendidikan & $1.609 .090,91$ & 7,31 \\
Listrik & $810.909,09$ & 3,68 \\
Komunikasi & $949.090,91$ & 4,31 \\
Bahan Bakar & $1.112 .727,27$ & 5,06 \\
Sosial & $581.818,18$ & 2,64 \\
Kebersihan & $409.090,91$ & 1,86 \\
Perabotan rumah tangga & $383.636,36$ & 1,74 \\
Kosmetik & $445.454,55$ & 2,02 \\
Tabungan dan lainnya & $5.978 .610,10$ & 27,17 \\
PBB & $12.893,94$ & 0,06 \\
Pajak kendaraan & $126.184,85$ & 0,57 \\
Pakaian & $1.094 .545,45$ & 4,97 \\
\hline Total pengeluaran/thn & $14.048 .597,97$ & $\mathbf{1 0 0 , 0 0}$ \\
\hline Total pengeluaran RT/thn & $\mathbf{2 2 . 0 0 7 . 7 6 4 , 9 7}$ &
\end{tabular}

Sumber: Data primer diolah (2013).

Pengeluaran untuk kebutuhan pangan yaitu padi-padian, tepung, dan mie. Rata-rata pengeluaran sebesar $\mathrm{Rp} 3.024 .500,00 /$ th dengan persentase 13,74\%. Kebutuhan petani umumnya mengkonsumsi padi hasil panen yaitu beras. Beras merupakan pola pangan pokok yang dikonsumsi, selain itu petani mengkonsumsi tepung dan mie instans sebagai pangan sampingan. Sedangkan pengeluaran untuk kebutuhan non pangan petani yaitu pendidikan. Rata-rata pengeluaran sebesar Rp1.609.090,91/th dengan persentase 7,31\%. Mayoritas anak-anak petani masih banyak yang duduk di bangku SD, SMP, dan SMA sehingga pengeluaran untuk pendidikan tidak terlalu besar karena tidak dipungut biaya karena adanya program BOS (Bantuan Operasional Sekolah). Hanya beberapa orang saja yang melanjutkan ke Perguruan Tinggi (PT). Remaja di Desa Margosari pada umumnya setelah tamat SMA mereka bertani.

Tingkat kesejahteraan dihitung menggunakan indikator Sajogyo (1997) dengan melihat kesejahteraan suatu rumah tangga berdasarkan dua pendekatan yaitu pendekatan pendapatan agroforestri dan pengeluaran agroforestri petani. Pendapatan petani dari hasil agroforestri yaitu kakao, kopi, pisang, jengkol, petai, durian, kelapa, lada, nangka, cengkeh dan karet. Sedangkan pengeluaran yaitu pupuk, bibit, pestisida, peralatan, dan tenaga kerja. 
Sajogyo (1997) menjelaskan bahwa tingkat kemiskinan diukur dengan menggunakan konsep pengeluaran per kapita per tahun yang diukur dengan menggunakan standar harga beras per kilogram di tempat dan pada waktu penelitian. Rata-rata total harga beras yang dikonsumsi rumah tangga sebesar Rp 7.455,00/kg, maka total pengeluaran per kapita per tahun setara harga beras untuk pengeluaran pangan dan non pangan sebesar Rp 628,00 kg/th. Kriteria kemiskinan per kapita per tahun setara harga beras petani Desa Margosari dapat dilihat pada Tabel 3.

Tabel 3. Kriteria kemiskinan Sajogyo (1997) berdasarkan per kapita per tahun setara beras petani Desa Margosari.

\begin{tabular}{|c|c|c|c|}
\hline No & Kategori & Jumlah Petani (orang) & Persentase (\%) \\
\hline 1 & Paling miskin (<180 kg beras/jiwa) & -- & -- \\
\hline 2 & $\begin{array}{l}\text { Miskin sekali } \quad(181-240 \quad \mathrm{~kg} \\
\text { beras/jiwa) }\end{array}$ & -- & -- \\
\hline 3 & Miskin (241—320 kg beras/jiwa) & 2 & 6,06 \\
\hline 4 & $\begin{array}{l}\text { Nyaris miskin } \quad(321-480 \quad \mathrm{~kg} \\
\text { beras/jiwa) }\end{array}$ & 17 & 51,52 \\
\hline 5 & Cukup (481—960 kg beras/jiwa) & 14 & 42,42 \\
\hline 6 & Hidup layak (>960 kg beras/jiwa) & -- & -- \\
\hline & Jumlah & 33 & 100,00 \\
\hline
\end{tabular}

Sumber: Data primer diolah (2013).

Berdasarkan hasil perhitungan yang telah dilakukan pendapatan rumah tangga petani yang masih tergolong miskin sebanyak $2 \mathrm{KK}$. Hal ini dikarenakan petani tersebut memiliki jumlah tanggungan sebanyak 4--5 dan pendapatan yang diperoleh tidak cukup untuk memenuhi kebutuhan sehari-hari. Petani yang termasuk dalam kategori nyaris miskin sebanyak $17 \mathrm{KK}$ dengan tanggungan keluarga sebanyak 3--4 orang merupakan petani yang hanya memiliki luas lahan sebesar 1--2,5 ha dan hasil penerimaan yang diperoleh hanya cukup untuk kebutuhan sehari-hari. Sedangkan untuk petani cukup dengan kategori sebanyak $14 \mathrm{KK}$ dengan jumlah tanggungan 3--4 orang. Hal ini berpengaruh terhadap tingkat pendapatan rumah tangga petani tersebut yang tidak terlalu besar karena sedikit jumlah anggota keluarga yang harus ditanggung.

Walaupun usahatani agroforestri finansial sudah layak, namun secara berdasarkan kriteria Sajogyo (1997) pendapatan hasil agroforestri belum dapat mensejahterakan petani. Oleh karena itu perlu pengkayaan jenis tanaman yang dapat meningkatkan pendapatan sebagai nilai tambah kesejahteraan petani.

\section{SIMPULAN}

1. Komposisi tanaman di lahan HKm Desa Margosari Kecamatan Pagelaran Kabupaten Pringsewu telah memenuhi kriteria HKm yaitu jumlah tanaman kayu lebih dari 200 batang/ha (400 batang/ha) dengan komposisi tanaman kehutanan $(28,88 \%)$, tanaman pertanian $(14,63 \%)$ dan kegiatan tanaman perkebunan $(56,47 \%)$.

2. Hasil agroforestri di Desa Margosari Kecamatan Pagelaran Utara Kabupaten Pringsewu layak secara finansial, dengan nilai Net Present Value (NPV) sebesar Rp 69.088.522,37/Ha, Benefit Cost Ratio (BCR) sebesar 1,96 dan Internal Rate of Return (IRR) sebesar 29\%. Namun, berdasarkan kriteria tingkat kesejahteraan Sajogyo (1997), pendapatan dari agroforestri belum dapat mensejahterakan petani Desa Margosari. 


\section{DAFTAR PUSTAKA}

Departemen Kehutanan. 2007. Peraturan Menteri Kehutanan Nomor 37 Tahun 2007 tentang Hutan Kemasyarakatan. Dephut RI. Jakarta.

Departemen Kehutanan. 2012. Peraturan Menteri Kehutanan Nomor No. P.14/MenhutII/2012 tentang Pedoman Penyelenggaraan Rehabilitasi Hutan dan Lahan Tahun 2012. Dephut RI. Jakarta.

Dinas Kehutanan Provinsi Lampung. 2011. Profil Desa Margosari. Pringsewu.

Harjadi, Sri Setyati. 1982. Pengantar Ekonomi. Buku. PT Gramedia. Jakarta.

Peraturan Daerah. 2004. No 8 Tahun 2004 Tentang Perizinan Usaha Pertanian dan Peternakan. Medan.

Rakhmat, J. 2001. Metode Penelitian Komunikasi. Buku. PT. Remaja Rosda Karya. Bandung. Sajogyo. 1997. Golongan miskin dan partisipasi dalam pembangunan. Jurnal. Prisma 4(3).

Sannia, B. 2013. Hubungan kualitas karet rakyat dengan tambahan pendapatan petani di desa program dan non program. Jurnal. JIIA 1(1):36-43p.

Siregar, T.H.S., S. Riyadi, dan L. Nuraeni. 2007. Cokelat: Pembudidayaan, Pengolahan, Pemasaran. Buku. Penebar Swadaya. Jakarta.

Siswanto dan E. Karmawati. 2012. Pengendalian hama utama kakao (Conopomorpha cramerella dan Helopeltis spp) dengan pestisida nabati dan agens hayati. Jurnal. Perspektif 2(11):103-99p.

Suharjito, Sundawati, Suyanto dan Utami. 2003. Aspek Sosial Ekonomi dan Budaya Agroforestri. Bahan Ajaran Agroforestri 5. World Agroforestry Centre (ICRAF). Bogor.

Sumantri, B., Sigit Priyono, B., Isronita, M. 2004. Analisis kelayakan finansial usahatani Lada (Piper ningrum, L) di desa kunduran kecamatan ulu musi kabupaten lahat sumatera selatan. Jurnal. Ilmu-ilmu Pertanian Indonesia 1(6): 32-42p.

Syahrani dan H.A. Husainie. 2003. Analisis kelayakan finansial pengusahaan kebun hutan tanaman durian di kabupaten kutai kertanegara propinsi kalimantan timur. Jurnal. Ekonomi Pembangunan 2(8)Hal: 137-146p.

Undang-Undang Republik Indonesia. 2004. No 18 Tahun 2004 Tentang Perkebunan. Jakarta. Wardoyo, E. 1997. Hutan Kemasyarakatan, Pengelolaan Hutan Partisipatif. PUSKAP FISIP USU, WIM dan Yayasan Sintesa. Medan. 